\title{
ENVIRONMENTAL CONTAMINATION BY TOXOCARA SP EGGS IN PUBLIC AREAS OF SALVADOR, BAHIA STATE, BRAZIL
}

\author{
Neuza Alcântara1 4, Emilia Bavia2, Rose Mary Silvão4 and Elza Carvalho' 3
}

\begin{abstract}
A survey of parasite eggs and cysts in soil and dog feces collected in public places of 23 boroughs of Salvador, a city in the Northeast of Brazil, was performed. High degree of contamination by Toxocara speggs was observed in all boroughs studied; other parasites found included: Ascaris lumbricoides, hookworms, whipworms and protozoan cysts. Parks and public gardens were more contaminated than streets and beaches for all parasites, including Toxocara sp.
\end{abstract}

Key-words: Toxocara sp. Ascaris lumbricoides. Contamination of soil. Dogfeces.

Toxocara canis and Toxocara cati are animal ascarids which accidentally infect man without completing their life cycle. The former is the most common agent of visceral larva migrans (VLM), a disease occuring during childhood and leading to clinical manifestations such as liver and spleen enlargement, fever and persistent hypereosinophilia ${ }^{2} 1719$.

Visceral larva migrans has a worldwide distribution, the largest number of cases reported from developed countries probabily indicates better diagnostic conditions than higher prevalences. The enzyme-linked immunoassay technique using as antigen Toxocara larvae secretory-excretory products, developed on the seventies 78 has facilitated the diagnosis of VLM and encouraged the development of epidemiological studies thoughout the world. Seroprevalence studies carried out in temperate and tropical countries have shown that up to $9 \%$ of the population have been infected by Toxocara $s p^{4}$. In São Paulo, Brazil, Chieffi et $\mathrm{al}^{6}$ found $3.6 \%$ Toxocara antibody positivity in 2025 individuals surveyed 6 . In addition, high number of soil and dog fecal samples have been found contaminated by Toxocara eggs in Brazil 4513 . However, to the best of our knowledge, only 26 clinical cases of VLM have been reported in this country 131011141518 , none of them in Bahia State.

In Salvador, contact of children with dogs and their excreta outside houses seems to be frequent Many homeless dogs can be seen in beaches, parks and streets.

1. Laboratório Central Prof. Gonçalo Moniz.

2. Faculdade de Medicina Veterinária.

3. Faculdade de Medicina e Instituto de Ciências da Saúde. Universidade Federal da Bahia.

Supported by CNPq project no $40.5332 / 82$.

Recebido para publicação em 08/04/87.
The present work aimed at measuring the contamination levels of soil and dog feces collected at public places by eggs of Toxocara sp in Salvador, Bahia, as the first step to study possible risk factors for children to develop visceral larva migrans.

\section{MATERIAL AND METHODS}

Two hundred and seventy seven dog fecal samples and 298 soil samples were collected from the following sites: 12 parks and public gardens, 18 streets (both inland and at the seaside) and 9 beaches, from 23 boroughs of Salvador. Seven to 8 soil samples and all feces found were taken from each of these sites. The geographical distribution of the boroughs in seen in Figure 1.

Soil samples were taken from sites at least one meter apart from any visible fecal material and examined within the first 24 hours for the presence of ascarid eggs by a technique described by Dubin and colleagues ${ }^{9}$. Feces were preserved in a merthiolateiodo-formalin solution ${ }^{5}$ and examined by the classical sedimentation technique.

\section{RESULTS}

From the 298 soil samples and 277 dog fecal samples examinated, soil was significatly $(\mathrm{p}<0.01)$ more positive $(24.8 \%)$ than feces (18.4\%) for eggs of Toxocara sp (Table 1).

The percentages of samples with Toxocara eggs are seen in Figure 1. Eggs in the soil or feces were found in all boroughs, although in two of them no Toxocara were detected on soil and or on dog feces laid on the ground (Figure 1).

Other parasites found in the soil included: Ascaris lumbricoides (26.8\%), Trichocephalus sp $(27.5 \%)$, hookworm (0.6\%) eggs and cysts of Isospora sp (2.8\%). 
Alcântara N, Bavia E, Silvão RM, Carvalho E. Environmental contamination by Toxocara sp eggs in public areas of Salvador, Bahia State, Brazil. Revista.da Sociedade Brasileira de Medicina Tropical 22: 187-190, Out-Dez, 1989.

The data were also analysed in terms of sites of samples collection (Table 2). Soil from parks and public gardens were more contaminated than beaches and streets. These differences were statistically significant for all parasites (Toxocara $s p$ and other parasites, $\mathrm{p}<0.01 ; A$. lumbricoides, p. $<0.05$ ). However, dog feces contaminated with Toxocara eggs were more prevalente in streets than in other sites $(\mathrm{p}<0.01)$.

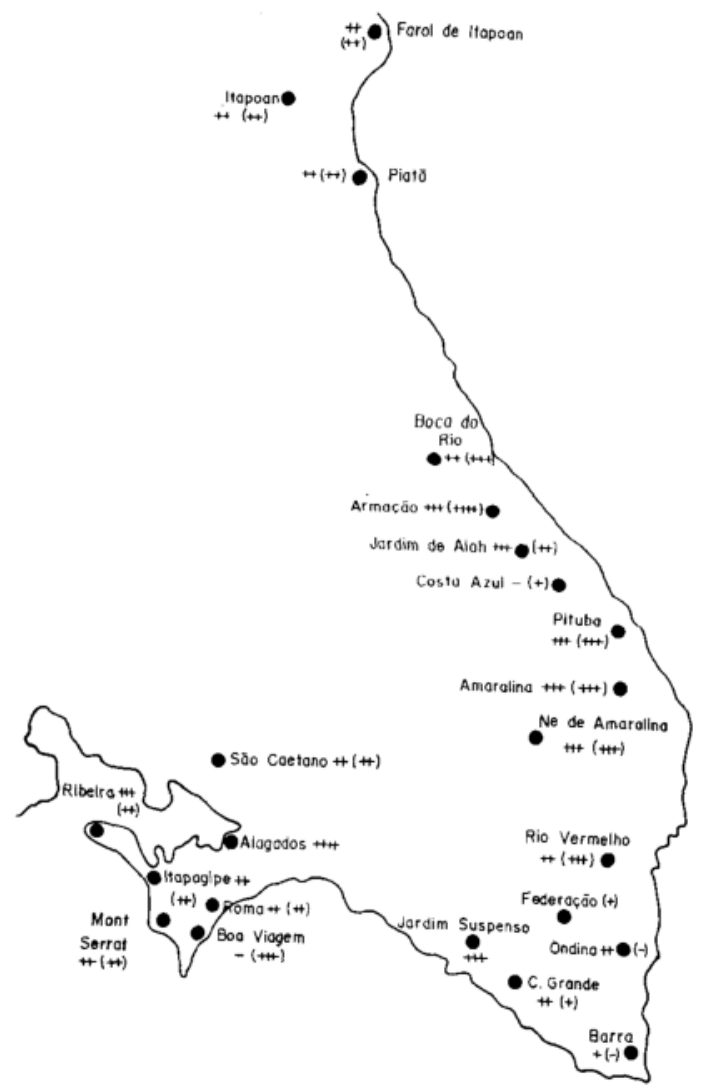

Figure 1-Percentage of Toxocara sp eggs in soil and (or) dog feces in the studied areas. A total number of 308 dog feces and soil samples were studied 23 boroughs. Symbols between brakets refer to results on soil samples. -, no positive samples found;,$+ \geq 10 ;++,>10$ and $\geq 20 \%$;,$+++>$ 20 and $\geq 40 \%$,,$++++>40 \%$.

\section{DISCUSSION}

The most important finding in this work was the observation of high degree of soil contamination by eggs of Toxocara sp. The degree of contamination, as expected, was higher than that described by Dubin and collalaborators in New York, who found a $10 \%$ rate of soil samples contaminated by animal ascarid eggs ${ }^{9}$. It was also higher than the data reported in Brazil by Chieffi \& Muller ${ }^{4}$ and Ferreira et al. ${ }^{12}$, who found $60 \%$ and $41.6 \%$ of parks contaminated by Toxocara eggs, since we found Toxocara eggs in all boroughs studied. These diferences could be explained by the relatively large number of samples studied in the present work or could be in fact a reflection of a higher prevalence of these parasites in Salvador in relation to the areas studied by other authors 412 . Although the number of viable eggs was not determined in the present study, the possibility that the eggs found in child's playing places may be swallowed and cause VLM should be taken into consideration.

The high degree of positivity for Toxocara $s p$ eggs in the soil as compared to dog feces could be accounted for by the persistence in the soil of the eggs, highly resistant to environmental conditions, for several years after the contaminated feces had been normally dispersed or washed away. Large egg burdens in a relatively small percentage of contaminated feces could also contribute to the observed situation.

The high prevalence of $A$. lumbricoides eggs at the studied areas very likely reflects inadequate sanitary conditions. In fact, this prevalence was even higher than that of Toxocara eggs.

\section{RESUMO}

Foi realizado um inquérito de ovos e cistos de parasitos em fezes de cães e solo coletados em locais públicos de 23 bairros de Salvador, uma cidade do Nordeste do Brasil, objetivando determinar os níveis de contaminação desses locais por ovos de Toxocara $s p$. Todos os bairros tiveram niveis altos de contaminaçāo por ovos de Toxocara sp. Outros parasitos encontrados foram: Ascaris lumbricoides, ancilostomideos, Trichocephalus sp e cistos de protozoários.

Table 1 - Toxocara $s p$ in dog feces and soil collected in 23 boroughs of Salvador.

\begin{tabular}{cccc} 
& & \multicolumn{3}{l}{ Results } \\
\cline { 2 - 4 } Samples & Posivitive n. (\%) & Negative no (\%) & Total no (\%) \\
\hline Soil & $74(24.8)$ & $224(75.2)$ & $298(100)$ \\
Feces & $51(18.4)$ & $226(81.5)$ & $277(100$ \\
\hline Total & $125(21.7)$ & $450(78.3)$ & $575(100)$
\end{tabular}

$\mathrm{x}^{2}=9.49, \mathrm{p}<0.01$ 
Alcântara N, Bavia E, Silvāo RM, Carvalho E. Environmental contamination by Toxocara sp eggs in public areas of Salvador, Bahia State, Brazil. Revista da Sociedade Brasileira de Medicina Tropical 22: 187-190, Out-Dez, 1989.

Table 2 - Parasite eggs and cysts in soil and in dog fecal samples collected from different public sites of Salvador.

\begin{tabular}{|c|c|c|c|c|c|c|c|c|c|c|c|c|}
\hline \multirow{3}{*}{$\begin{array}{l}\text { Site of } \\
\text { Collection }\end{array}$} & \multicolumn{7}{|c|}{ Soil samples } & \multicolumn{5}{|c|}{ Dog fecal samples } \\
\hline & \multirow{2}{*}{$\begin{array}{c}\text { Ne } \\
\text { Examined }\end{array}$} & \multicolumn{2}{|c|}{ Toxocara sp } & \multicolumn{2}{|c|}{ A. lumbricoides } & \multicolumn{2}{|c|}{ Other parasites* } & \multirow{2}{*}{ № Exam. } & \multicolumn{2}{|c|}{ Toxocara sp } & \multicolumn{2}{|c|}{ Other parasites** } \\
\hline & & Positive & $\%$ & Positive & $\%$ & Positive & $\%$ & & Positive & $\%$ & Positive & $\%$ \\
\hline $\begin{array}{l}\text { Streets } \\
\text { Parks and }\end{array}$ & 134 & 38 & 28.4 & 40 & 29.9 & 42 & 31.3 & 143 & 37 & 25.9 & 129 & 90.2 \\
\hline $\begin{array}{l}\text { public } \\
\text { gardens }\end{array}$ & 96 & 31 & 32.3 & 30 & 31.3 & 38 & 39.6 & 69 & 12 & 17.4 & 63 & 91.3 \\
\hline Beaches & 68 & 9 & 13.2 & 10 & 14.7 & 12 & 17.6 & 65 & 7 & 10.8 & 59 & 90.8 \\
\hline Total & 298 & 78 & 26.2 & 80 & 26.8 & 92 & 30.9 & 277 & 56 & 20.2 & 251 & 90.6 \\
\hline
\end{tabular}

* including whipworm eggs and protozoan cysts.

** including whipworm, hookworm eggs and protozoan cysts.

$\mathrm{x}_{2}^{2}$ of differences observed in percentages of positive soil samples in the sites of collection for: Toxocara sp $=7.55, \mathrm{p}<$ $0.01 ;$ A lumbricoides $=6.64, \mathrm{p}<0.05 ;$ other parasites $=8.96, \mathrm{p}<0.01$.

$\mathrm{x}^{2}$ of differences observed in percentage of positive dog fecal samples in the sites of collection for: Toxocara sp $=6.75, \mathrm{p}$

$<0.01$; other parasites $=0.03,<0.05$.

Parques e jardins públicos tiveram taxas de contaminação mais elevadas para todos os parasitos, quando comparados com ruas e praias.

Palavras-chaves: Toxocara sp. Ascaris lumbricoides. Contaminação de solo. Fezes de cães.

\section{REFERENCES}

1. Abe-Jacob CM, Zuccolotto SMC, Peres BA, BachRizetti BC, Oselka GW, Camargo ME, Chen S. Larva migrans visceral por Toxocara canis. Estudo das características clínicas e laboratoriais de 7 casos humanos. Revista da Associação Médica Brasileira 30:187-91, 1984.

2. Beaver $\mathbf{P C}$. The nature of visceral larva migrans. The Journal of Parasitology 55:3-12, 1969.

3. Chiattone CS, Chieffi PP, Paes RAP. Síndrome de larva migrans visceral em adulto. Apresentação de um caso. Revista do Instituto Adolfo Lutz 43:85-88, 1983.

4. Chieffi PP, Muller EE. Prevalência de parasitismo por Toxocara canis em cães e presença de ovos de Toxocara $s p$ no solo de localidades públicas da zona urbana do municipio de Londrina, Estado do Paraná, Brasil. Revista de Saúde Pública 10:367-372, 1976.

5. Chieffi PP, Muller EE. Estudo da variação mensal na contaminação do solo por ovos de Toxocara sp (Nematoda, Ascaroidea), na zona urbana do municipio de Londrina, Estado do Paraná, Brasil. Revista do Instituto Adolfo Lutz 38:13-16, 1978.
6. Chieffi PP, Veda M, Camargo ED, Souza AMC. Sindrome de larva migrans visceral: Pesquisa de anticorpos anti-Toxocara em pacientes com hipereosinofilia. Revista da Sociedade Brasileira de Medicina Tropical 20 (supl): 85, 1987.

7. De Savigny DH. In vitro maintenance of Toxocara canis larvae and a simple method for the production of Toxocara $\mathrm{ES}$ antigen for use in serodiagnostic tests for visceral larva migrans. The Journal of Parasitology 61:781-782, 1975.

8. De Savigny DH, Voller A, Woodruff AW. Toxocariasis: serological diagnostic by enzyme immunoassay. Journal of Clinical Pathology 32:288, 1979.

9. Dubin S, Segall S, Martindale J. Contamination of soil in two city parks with canine nematode ova including Toxocara canis: preliminary study. American Journal of Public Health 1242-1245, 1972.

10. Faria R, Rstom FM. Larva Migrans Visceralis (Sindrome de Loeffler por Toxocara canis). Pediatria Moderna 16:190-196, 1981.

11. Ferraz CN, Kerbauy J, Farhat CK, Claro JT, Silva MP. Eosinofilia relacionada à "larva migrans" visceral. Revista da Associação Médica Brasileira 26:253-254, 1980.

12. Ferreira LF, Oliveira EL, Camillo-Coura L. Sobre a presença de ovos de Toxocara em praças da cidade do Rio de Janeiro. Revista da Sociedade Brasileira de Medicina Tropical 10:51-54, 1976.

13. Josephson SL. Human toxocariasis. Clinical Microbiology News Letter 10:25-25, 1988.

14. Köberle F, Artigas PT. Considerações em torno de dois casos de "larva migrans" visceral. In: Resumos do VI Congresso Brasileiro de Parasitologia. Belo Horizonte P. $128,1981$.

15. Salzman M. Relato de Caso de Toxocariase. Jornal de Pediatria 59:205-206, 1985. 
Alcântara N, Bavia E, Silvâo RM, Carvalho E. Environmental contamination by Toxocara sp eggs in public areas of Salvador, Bahia State, Brazil. Revista da Sociedade Brasileira de Medicina Tropical 22: 187-190, Out-Dez, 1989.

16. Sapero JJ, Lawless DK. "MIF" stain preservation technic for identification of intestinal protozoa. American Journal of Tropical Medicine and Hygiene 2:613$619,1953$.

17. Snyder CH. Visceral larva migrans. Ten years of experience. Pediatrics 28:85-91, 1961.

18. Teles W. Afecção provocada pela "larva migrans vis- ceral". Revista Brasileira de Medicina 13:697-698, 1956.

19. Woodruff AW. Toxocariasis. British Medical Journal 3:663-699, 1970.

20. Zago Filho H, Barreto MP. Estudo sobre a prevalência e intensidade de infestação por helmintos intestinais em cães e gatos de Ribeirão Preto. SP. Revista Brasileira de Malariologia e Doenças Tropicais 9:295-304, 1957. 